\title{
Yaratıcı Drama Yönteminin Grafik Tasarım Bölümü Reklâmcılık Derslerinde Kullanılmasının Öğrenci Görüşlerine Göre Değerlendirilmesi
}

\author{
A. Hamit GÜMÜŞLÜ*
}

Erciyes Üniversitesi

\begin{abstract}
$\ddot{O ̈ z e t}_{\text {zet }}$
Bu çalışma, Grafik Tasarım Bölümü Reklâmcılık derslerinde yaratıcı dramanın bir öğretim yöntemi olarak kullanıldı̆̆ 4 haftalık bir deneyimin öğretim üzerindeki etkilerini araştırmaktadır. Çalışma, 2009-2010 ĕgitim ögretim yılında Erciyes Üniversitesi, Güzel Sanatlar Fakültesi, Görsel İletişim Tasarımı Bölümü, Bahar Dönemi, 3. sınıf öğrencileriyle birlikte gerçekleştirilmiştir. Çalışmalar, sınıf ve çalışma stüdyosunda 4 hafta boyunca, her hafta 6 ders saati olmak üzere, toplam 24 ders saatinde gerçekleştirilmiştir. Yorum ve değerlendirme, yaratıcı drama çalışmaları kullanılarak ve kullanılmadan ürettikleri grafik tasarımların karşılaştırılmasıyla yapılmıştır. Ayrıca, 4 haftalık sürecin sonunda ögrencilerden çallşmalarla ilgili duygu ve düşüncelerini bir mektup yazarak anlatmalart istenmiştir. Bu mektuplardan elde edilen veriler de içerik analizi türlerinden olan "frekans analizi" ile incelenmiştir. $B u$ incelemede ögrencilerin etkinlikler sırasında yaşadiğı duygular ve düşüncelerden kategoriler oluşturulmuş ve yorumlanmıştır. Uygulama sonunda ulaşılan sonuç yaratıcı dramanın grafik tasarım ve reklâmcılık derslerinde etkili bir yöntem olarak kullanılabileceği yönünde olmuştur.
\end{abstract}

Anahtar Sözcükler: Reklâmcılık, yaratıcı drama, grafik tasarım.

\begin{abstract}
This study investigates the effects of using creative drama on education in advertising courses of graphic design department. The study was carried out with third grade students of Visual Communication Design, Fine Arts Faculty of Erciyes University. It was carried out in two phases. In the first phase, the lectures were given in normal state, without methods of creative drama. In the second phase, on the other hand, creative drama methods were used. The conclusion was made upon a comparison of relevance to the aim and artistic success between the graphic designs of the first phase and the second one, in which creative drama techniques were used. The study was carried out with periods of 6 hours in a week, and for 4 weeks (24 hours in total) in classrooms and study studios. At the end of the process, students have written their thoughts and feelings in a letter about the study. The data obtained from this letter has been examined by the frequency analysis which is the one type of content analysis. In this study, student's emotions and ideas occurred during activities divided into similar categories and interpreted. The conclusion of the study is that the creative drama can be used as an efficient method in graphic design and advertising courses.
\end{abstract}

Key Words: Key Words:_Advertising, creative drama,_sraphic design.

* Yrd. Doc. Dr. Erciyes Üniversitesi Güzel Sanatlar Fakültesi Görsel İletişimi Tasarımı Bölümü, E-posta: hgumuslu@erciyes.edu.tr 


\section{Giriş}

Üniversitelerin Güzel Sanatlar Fakülteleri Grafik Tasarım bölümlerinde yürütülen "Reklâmcılık" derslerinde yeni yetişecek reklâmcı adaylarına, alanla ilgili temel kavramlar uygulamalı ve kuramsal olarak gösterilmektedir. Ancak reklâmcılık dersleri yürütülürken öğretimde (reklâm kampanyası hazırlama, hedef kitleyi saptama, hedef kitlenin gereksinimlerini, eğitim durumunu vb saptama, hedef kitleye uygun düşünce üretimi, düşüncenin mesaja çevrilmesi, fikrin sloganlaştırılması, metin ve görsellere karar verme, afiş, el ilanı, TV reklâmı üretme vb) bazı eksikliklerle karşılaşılmaktadır.

Örneğin, bu çalışmanın yürütüldüğü ilgili sınıf öğrencilerinin katıldıkları (Kayseri Saray Halı ve Hayvancılık Anonim Şirketi'nin, Erciyes Üniversitesi ile beraber düzenlediği) bir amblem/logo yarışmasının ödül töreninde önemli eksiklikler saptanmıştır. Sözü edilen yarışmada ödüle layık görülen öğrencilerin yaptıkları çalışmaların grafiksel gerekçeleri (renk, form, kompozisyon vb) hakkında bilgi vermeleri istenmiş, buna karşın öğrencilerin yaptıkları çalışmaları ifade etmekte zorlandıkları, alanlarıyla ilgili konularda dahi önemli ifade sorunları yaşadıkları gözlemlenmiştir. Öğrencilerin öğrenim gördükleri alanın ve özellikle reklâmcılığın iletişim, kendini ifade etme ve sunum becerisi gerektirdiği, buna karşın uygulanan öğretim programında bunu geliştirebilecek bir unsurun bulunmaması göz önünde tutularak hem bu soruna hem de proje üretimi sırasında karşılaşılan -hakem tarafından gereksiz bulunan bir genelleme bu bölümden kaldırılmıştır- buna benzer sorunlara çözüm getirmek amacıyla bir yöntem arayışına girilmiştir.

Eğitim ve öğretimde yeni arayışlara girilmesinin yaşanan zamanın bir gereği olduğu ve "uygucu bir ĕgitim anlayışının egemen olduğu bir ĕgitim dizgesinde yaratıcılı̆̆ın geliştirilmesi ve yaratıcı bireylerin yetiştirilmesinin gün geçtikçe zorlaştığı” (Adıgüzel, 2006a: 220), pratikte yaşanan birçok eksiklikten dolayı kolaylıkla görülmektedir. Bu noktada, yaratıcı dramanın sunduğu olanaklarla birçok eksikliği giderebileceği düşünülmüştür. Örneğin, yaratıcı drama, sunduğu grup çalışması süreci içinde “...Yaşayarak öğrenme, bilgi edinmenin yanı sıra sözel anlatımın gelişmesi ve toplumsallaşmanın sağlanmasında da önemli yararlar” sağlamaktadır (San, 2002: 84, Aktaran: Aykaç, 2005: 137). Adıgüzel'e göre: (2006a: 220). Sanat eğitiminde ‘drama’ya insani özü ve toplumsallaşma, kendi kendine güven sağlama ve yaşayarak öğrenme niteliklerinden ötürü kendine özgü çok önemli bir kol, bir eğitim yöntemi olarak yeterince işlerlik kazandırılmalıdır."

$\mathrm{Bu}$ araştırmanın çalışma grubunu oluşturan Erciyes Üniversitesi Güzel Sanatlar Fakültesi, Grafik Tasarım bölümü öğrencilerinin yukarıda belirtilen ve bir iletişim sorunu olarak nitelendirilebilecek olan "projelerinin sunumu konusunda duyulan rahatsızlık ve çekingenlik" aslında birçok eksiklikten, sorundan yalnızca birisidir. Üstelik bu sorunların yalnızca ilgili üniversitenin öğrencileriyle sınırlı olmadığ1, genel anlamda Türkiye'deki üniversitelerin grafik eğitim ve öğretim sistemiyle de ilgili olabileceği düşünülmektedir. Birbirlerine ayrılmaz bir şekilde bağlı olan bu sorunlar, grafik tasarım için Şart olan grup içi çalışmada uyum, yaratıcılık, farklı düşüncelere ve değişime, dönüşüme açık olma, kendini ifade edebilme cesareti gibi konularda yoğunlaşmaktadır. Dolayısıyla, yaratıcı drama, genel anlamda sanat; özelde de grafik tasarım öğrenimi gören birçok öğrencinin gereksinimlerine önemli katk1 
sağlayacak bir yöntem gibi görünmektedir. Çünkü bu alternatif eğitim ve öğretim yöntemi sayesinde "yaratıcı, üretken, yalnız belli somut ürünler vererek değil, fikirde de üretken olan, yaratıcı kararlar alabilen, değişik olmaktan ve değişiklik yapmaktan korkmayan, dilini iyi kullanan, eleştirel ve yargılayıcı olabilen gençler yetiştirmek" mümkün olabilmektedir (San, 2002: 85, Aktaran: Aykaç, 2005: 137).

Kısaca, yaratıcı dramanın eğitime getirdiği yeni çalışma yöntemleriyle grup içi iletişimi sıklaştırması, yaratıcılığın önünü açması, yaşantılara dayalı bir süreç olması nedeniyle grafik öğretimi alanına önemli katkılar sunacağı düşünülmüştür. Ayrıca, canlandırmalara dayanan öğrenmelerin kalıcılığı ve katılımcılara kendilerini ifade etme, kendilerine güven duyma konularında sunduğu deneyimler nedeniyle yaratıcı dramanın grafik tasarım alanında ve reklâmcılık derslerinde yukarıda sözü edilen sorunları etkili bir şekilde çözme potansiyeli taşıması olasılığı üzerinde durulmuştur.

\section{Reklâmcılık Kavramı ve Reklâmcılık Eğitimi}

Reklâmc1lık sözü günümüzde birçok kişi için, yalan ve uydurma yollarla bir malı satmaya çalışma çabaları olarak algılanmaktadır.Bu anlayışın kaynağında insanların reklâmcılıkla ilgili yaşadıkları sayısız olumsuz deneyim vardır. Teknik ifade ile "yanıltıcı reklâmcılık” çok yaygınlaşmış bulunmaktadır. Reklâmcıların önemsiz olmayan bir kısmı gerçekten de yanıltıcı reklâmcılığı bir yöntem olarak benimsemiş bulunmaktadırlar. Kural ve kaidelere, uluslararası reklâm etik kurallarına aldırmadan bir mal ya da hizmeti satmak uğruna her türlü ikna yöntemine başvurmaktadırlar. Ancak reklâmcılıkla ilgili sağlıklı genellemeler yapmak için bu tür örnekler yeterli değildir. Öncelikle, reklâmcılıkla ilgili kuramsal çalışmalara öncülük eden kişilerin düşüncelerine başvurmak gerekmektedir.

Reklâmcılıkla ilgili ilk sistematik çalışmalar yürüten alanın önemli kuramcıları reklâmcılığın kaynak israfı (Bach, 1962: 521); kaynakların uygunsuz bir şekilde tahsisi (McConnell, 1963: 500-501), haksız rekabeti arttırma ve tekel yaratma (Colston E. Warne, 1962: 12), tüketicileri kandırma, egemenliklerini zedeleme ve tüketicilerde arzu edilmeyen istekler yaratma (Caves, 1964:102; Boulding, 1962: 513; Colston E. Warne, 1962:11 vd.) gibi etkiler üretme olasıllğından söz etmişlerdir.

Buna karşın, yine reklâmcılık alanında söz sahibi olan başka kuramcılar, yukarıdaki düşüncelerin olasılık dâhilinde olduklarını kabul etmekle birlikte, reklâmcılığın vazgeçilmez olduğunu ve olumlu etkilerinin ağır bastığını savunmuşlardır. Bu düşüncelere göre doğru yöntemler kullanılması durumunda reklamcılık, sağlıklı bir rekabet yaratabilmekte (Beckman, 1968: 2-3), maliyetleri ve dolayısıla fiyatları düşürebilmekte (Morgens, 1962: 12), ürünler hakkında doğru bilgi sağlayarak tüketicileri bilinçlendirmekte ve doğru seçim yapma şansı sunmakta (J. Stigler, 1966: 200) kaynak israfinı azaltıp işletmelerin dolayısıyla ulusal ekonomilerin gelişmesine katkı sağlayabilmektedir (Warkham, 1964: 3137).

Reklâmcılık, kapitalizmin serbest rekabetçi dönemine dayanan bir olgudur ve tek başına tekel yaratma gibi, haksız rekabet yaratma gibi özellikleri zayıftır. İkincisi; reklâmcılık, her şeyden önce ve her koşulda etkili bir pazarlama yöntemidir. Doğru kullanıldığında ülke ekonomilerine ve tüketicilere ciddi yararlar sağlayabilmektedir. Buna karşın, yanlış kullanılması halinde de başta tüketiciler, sonra ülke ekonomisi ve gereksiz tüketime yol açması nedeniyle bütün dünya için bedelleri ağır olabilmektedir. 
Açıktır ki, grafik tasarım bölümlerinde reklâmcılık dersleri, reklâmcılığın ciddi anlamda yozlaşmaya başlaması olgusunu dikkate alarak ve bu sorunun çözümünün çağın gereklerine uygun eğitim ve öğretim yöntemlerinden geçtiğinin bilincinde olarak yürütülmelidir.

\section{Reklâmcılık Derslerinde Neden Yaratıcı Drama?}

Grafik Tasarım bölümlerinde yürütülen reklâmcılık derslerinde yeni yetişen reklâmcılara öncelikle reklâmcılığın yalnızca bir mal satma işi olmadığı aynı zamanda toplumsal sorumlulukları bulunan bir alan olduğu gösterilmektedir.Doğru bilgi vermeyi ilke edinen, tüketicileri korumaya gayret eden, rekabete destek veren, topluma karşı sorumluluklarını hisseden, kaynak israfının karşısında yer alan, kapitalizmin tekelci yönlerinin olumsuz etkilerini tüketiciler ve toplum nezdinde azaltmaya çalışan ahlaklı reklâmcılar yetiştirmek hedeflenmektedir. Bu amaçla öğrencilerin piyasaya girdikleri zaman seslenecekleri tüketicileri tanımaları, onların gerçek ihtiyaçlarını belirlemeleri ve seslendikleri insanlarla empati kurmaları konusunda yöntemler gösterilmeye çalışılmaktadır. Ancak hâlihazırdaki derslerin yapısıyla (teorik bilgilerle ve bu bilgiler 1şı̆̆ında gerçekleştirilen afiş, reklâm vb. uygulamalarla) bu amaçları gerçekleştirmek çoğunlukla mümkün olamamaktadır. Buna karşın, reklâm kampanyası sürecinde bir aşamay1 "yaratıcı dramanın doğaçlama, rol oynama gibi tekniklerinden yararlanarak", (Adıgüzel, 2006b: 21) canlandırdığımızda öğrencilerin konuyla daha ilgili, daha aktif oldukları ve sorunları çözme konusunda daha azimli ve gayretli davrandıkları gözlemlenmiştir.

Yaratıcı dramanın, “örgün, yaygın ve hizmet içi eğitimde başlı başına bir ders olarak verilebilmesi” ve bunun yanı sıra "diğer derslerin ögreniminde de bir yöntem olarak kullanılabilmesi” (Okvuran, 2006: 196) noktasından hareketle, reklâm kampanyası hazırlığı sırasında da yaratıcı drama aşamalarından, başta canlandırma olmak üzere yararlanılabileceği düşünülmüştür.

$\mathrm{Bu}$ arada, güzel sanatlar fakültelerinde yürütülen derslerde yaratıcı dramanın öğrencilere kazandırabileceği -öncelikle- kendini tanıma, karşıdakini anlamaya gayret etme, dünyanın yalnızca kendisiyle sınırlı olmadığını anlama becerilerinin önemini de belirtmek gerekir. Yaratıcı drama, gerçek hayat ile kurgusal hayatın özümsendiği bir alan (San, 2006: 53) ve bir sanatsal biçim olarak, bireyi kendi fantezilerine kapanmaktan, kendi istekleriyle sınırl kalmaktan kurtaran bir yöntemdir (Sağlam, 2006: 64). Dolayısıyla yaratıcı drama, bir bakıma hem diğer sanat bölümlerinde öğrenim gören öğrenciler için, hem de bir sanatçı olarak grafik tasarımcının yaratıcılık ile önündeki engelleri de kaldırabilen bir yöntemdir. Çünkü bir sanatçının engelsizce yaratıcı olabilmesi için klişeleşmiş düşünme biçimini bir yana bırakmış olması ve kendi kişiliğini tanımış olması gerekmektedir.

Empati kavramının en dolayımsız kazanılabileceği alanlardan birisinin yaratıcı drama olması, oyun ile gerçeklik arasındaki ikircikli durumun sağladığı bir avantajla ilgilidir. Bu avantaj, dramanın bir gücü ve kolaylıkla benimsenmesini de sağlayan bir özelliktir. Çünkü oynanan rolün gerçek olmayışının bilinmesi, canlandırılan kişi olarak kalma zorunluluğunun olmayışı, oyuncuyu gerçek hayatta bir risk alma ve kendini tehlikeye atma, bir bedel ödeme sorumluluğundan korumuş olmaktadır (San, 2006: 54). Dolayısıyla, reklamcılık derslerinde öğrenciler yaratıcı drama sayesinde alanlarıyla ilgili çok önemli bilgileri bir bedel ödeme riski almadan öğrenebilecekledir. Böylelikle, 1sınma oyunları, canlandırmalar, 
doğaçlamalar yoluyla, hedef kitle de daha iyi tanınabilecek ve reklamcının hedef kitleyle empati kurması kolaylaşmış olacaktır. Bu, aynı zamanda hedef kitleyi "aldatılabilecek bir potansiyel” olarak gören yanlış anlayışları da zayıflatabilecek bir faydaya da yol açabilecektir.

Öyle görülüyor ki, grafik tasarım, reklâmcılık ve yaratıcı drama arasında etkileşime açık birçok yön bulunmaktadır. Reklâmcılık ve grafik tasarım öğretimine yaratıcı dramanın sunabileceği olası katkılar bu etkileşimin çok olumlu bir seyir izleyebileceğini göstermektedir.

\section{Çalışmanın Amacı}

$\mathrm{Bu}$ çalışma, grafik tasarım bölümlerinde uygulanan geleneksel eğitim sistemine yaratıcı dramanın sağlayabileceği olası katkıları tartışmak ve üniversitelerin grafik tasarım bölümlerinde, yaratıcı drama başta olmak üzere çağın gerektirdiği eğitim ve öğretim yöntemlerinin kullanılması sürecine katkıda bulunmayı amaçlamaktadır. Bu yolla, yeni yetişen grafik tasarımcıların ve reklâmcıların kendilerine güvenen, kendilerini ifade etme konusunda zorlanmayan, topluma karşı sorumluluklarını bilen, toplumun bir parçası olmayı başarabilen, dolayısıyla toplumdaki insanları "kandırılacak müşteri” olarak görmeyecek bireyler olarak yetişmeleri olasıllı̆ı artmış olacaktır.

Yaratıcı drama, hem eğitimde kullanılabilecek bir yöntem olarak reklâmcı adaylarına alanlarını daha iyi tanıma ve uygulama şansı verebildiği için, hem de insanın gelişimine katkı sağlayabildiği; insanı kendisiyle ve bulunduğu toplumla barışık hale getirebildiği için eğitimde ve sanatta özel bir öneme sahiptir. Ayrıca bir sanat ve eğitim alanı olarak da bu sürece önemli katkılar sağlayabilecek gibi görünmektedir.

\section{Araştırma sorusu}

Yaratıcı drama yönteminin grafik tasarım bölümü reklamcılık derslerinde kullanılması ile ilgili öğrenci (katılımc1) görüşleri nelerdir?

\section{Çalışmanın Yöntemi}

Çalışmada nitel araştırma yöntemlerinden görüşme kullanılmıştır. Öğrenci görüşleri çalışmalardan sonra yazdırılan mektuplardan elde edilmiştir.

\section{Çalışma Grubu}

Uygulama, Erciyes Üniversitesi Güzel Sanatlar Fakültesi Görsel İletişim Tasarımı Bölümü, 3. sınıfta okuyan ve Reklâmcılık dersini alan, yaşları 19 ile 26 arasında değişen, 6'sı kız, 10'u erkek toplam 16 öğrenciyle birlikte grafik tasarım bölümü atölyelerinde gerçekleştirilmiştir.

\section{Veri toplama aracı}

Çalışmanın nitel verileri çalışmalar sonucunda öğrencilere yazdırılan mektuplar ile elde edilmiştir. Mektuplar çalışmanın sonunda öğrencilere yazdırılmış ve çalışmalara katılan 16 kişiden 16 mektup toplanmıştır. Bu mektupların 11'i 2'şer sayfa, 1'i 3 sayfa, geriye kalan 4'ü ise 1'er sayfa olmak üzere toplam 29 sayfadir. 


\section{Verilerin Analizi}

$\mathrm{Bu}$ çalışmada öğrenci mektuplarıyla elde edilen nitel veriler bilgisayar ortamına aktarılmış ve içerik analizi ile araştırmanın amaçları doğrultusunda değerlendirilmiştir.Analiz sürecinde mektuplar öncelikle kelime, cümle, paragraf olarak irdelenmiş ve kelime kodlaması yapılmıştır. Kodlamalar sonucunda elde edilen ortak kodlar temalar altında bütünleştirilmiştir. Çalışma sonucunda "Kendini İfade Etme, Farkındalık, Empati ve İletişim” temaları ortaya çıkmıştır. Elde edilen bu temalar ile öğrenci görüşleri aslına sadık kalınarak bulgular kısmında verilmiştir.

\section{Uygulama Süreci}

Uygulama öncesinde bir ön hazırlık yapılarak kapsamı, amacı ve yeri belirtilen yaratıcı drama çalışması ile ilgili bir taslak program oluşturulmuştur.

Hazırlanan program çerçevesinde reklâmcılık dersinin 19 Şubat 2010 tarihindeki bahar döneminin ilk hafta dersinde reklâmcılıkla ve reklâm kampanyalarıyla ilgili genel bilgiler, kavramlar ve örnekler verilmiş, ikinci hafta için ödev olarak "Kızılderililere mikrodalgalı firın satışı” kampanyası için fikir üretmeleri istenmiştir.

Bir sonraki hafta, 26 Şubat 2010 tarihinde, dersin 1. saatinde, öğrencilerin ürettikleri fikirleri tartışmaları ve reklâmın ana vaadini (mesajı) oluşturmaları istenmiştir. Sonraki saatlerde, oluşan mesajların bir slogan ve metne çevrilmesi ve bir taslak afişe uygulanması istenmiştir. 4 ders saati boyunca atölye ortamında çalışan 16 kişilik sınıf mevcudundan yalnızca 8 afiş taslağı çıktığ 1 son saatte yapılan değerlendirme çalışması sırasında anlaşılmıştır. Geriye kalan 8 öğrenci değişik nedenlerle afiş üretemediklerini söylemişlerdir. $\mathrm{Bu}$ gerekçelerin bazıları şunlardır: "Düşünce olarak tam karar veremedim.”, "Bu iş bana göre değil.”, "Uğraşıyorum ama yapamıyorum.” Ortaya çıkan taslaklar ise, ciddi hatalar taşıyan çalışmalar olarak kayda geçmiştir. Örneğin, Kızılderililere seslenmeye çalışan öğrencilerin çoğu, alaycı, küçümseyici bir bakış açısıyla tasarım yapmışlardır (bkz. Şekil: 1, 2). Ayrıca, çalışmaların değerlendirilmesi yapılırken, "Kızılderili” konusu verildiği andan itibaren "Tarihteki Kızılderililer” gibi yanlış, ön yargılı bir anlamdan yola çıkıldığı anlaşılmıştır. Bu yanlış anlamanın etkisiyle öğrencilerin, yaptıkları afişlerle, iki yüzyıl önce yaşayan Kızılderililere seslenme hatasına düştükleri görülmüştür.
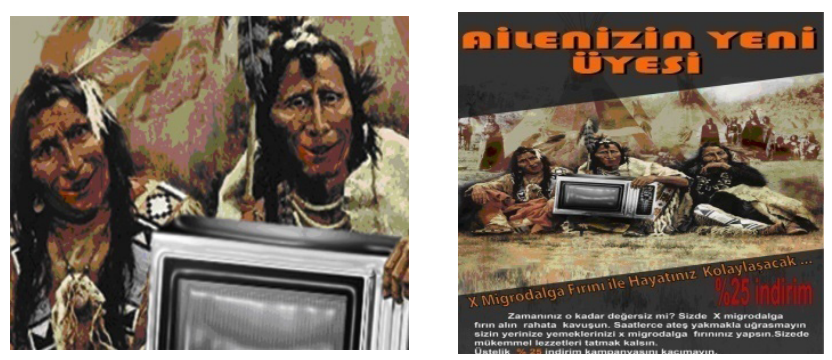

(Şekil: 1) Güzel Sanatlar Fakültesi, Grafik Tasarım bölümü 3. sınıf öğrencisine ait bir reklâm afişi örneği. Çalışma, Reklâmcılık dersinde Kızılderililere seslenen bir kampanya çerçevesinde gerçekleştirilmiştir. Özelliği ise, Kızılderilileri çirkinleştirip komik duruma düşürmeye çalışan bir afiş olmasıdır (solda afişin tamamı, sağda afişten bir detay). 

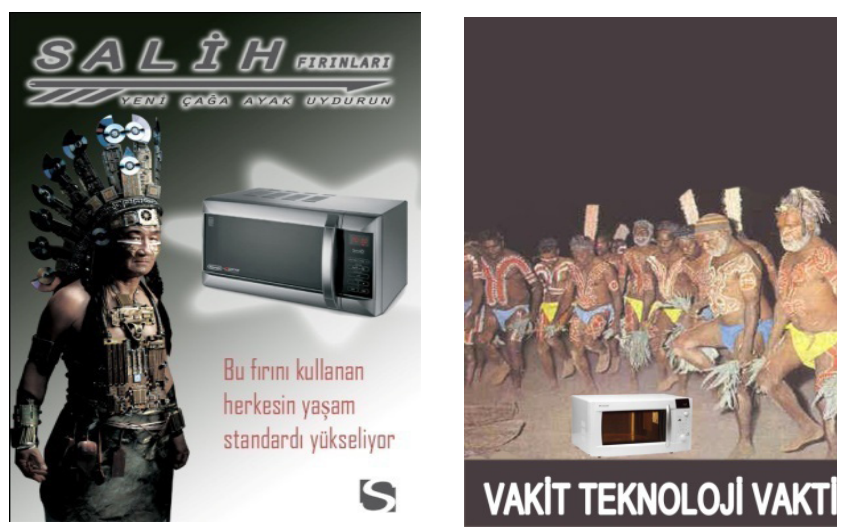

(Şekil: 2) GSF, Grafik Tasarım bölümü 3. sınıf öğrencilerinin Reklâmcılık dersi için hazırladıkları iki afiş örneği. Afişlerde estetik kaygının eksikliği hemen göze çarpmaktadır. Ayrıca afişler teknik yönden ciddi sorunlar da taşımaktadırlar. Örneğin, tanımsız renklerin kullanımı bask1 sırasında sorunlara yol açan bir hata olarak görülmektedir. Ayrıca tipografide önemli hatalar yapılmış. Örneğin, soldaki afişte kullanılan font okunaksız, ayrıca gölgelendirmelerle daha da okunaksız hale getirilmiştir. Sağdaki afişte ise, ne amblem, ne alt metin bulunmuyor ve başlık da tasarımın bir afiş olarak algılanmasını sağlayamamış. Bir resim ve altında resmi açıklayan başlıktan ibaret. Tasarımlar, içerik anlamında da ciddi sorunlar taşıyorlar. Soldaki afiş Kızılderililere seslenirken; yine Kızılderililerle alay etme hatasına düşmüş bulunuyor. Sağdaki afiş ise, daha da ağır sorunlar taşıyor. Çünkü öncelikle, Kızılderilileri büsbütün aşağılayan bir görsel kullanılmış. Ayrıca araştırma yapmamanın bir sonucu olarak tasarımda, Amerika kıtasının "yerlileri” olan Kızılderililer yerine Yeni Zelanda "yerlileri” kullanılmış.

27 Şubat 2010 tarihinde gerçekleştirilen bir sonraki derste, önceki derste yapılan hataları, eksiklikleri göstermeye yardımcı olmak amacıyla ve daha önce hazırlanan yaratıcı drama taslak programına uygun olarak, yaratıcı drama yöntemleri kullanılarak bir başka reklâm kampanyası çalışmasının hazırlıkları yapılmıştır. Bu çerçevede ders, grafik tasarım eğitimi, reklâmcılık ve yaratıcı dramanın öğretimde kullanılmasıyla ilgili genel bilgilendirmeye ve bu konudaki fikir alışverişine ayrılmıştır.

Sonraki haftalarda reklâmcilık dersleri ( 5/12/19 ve 26 Mart 2010 tarihlerinde 6'şar saat olarak) yaratıcı drama yöntemi kullanılarak gerçekleştirilmiştir. Bu çalışmalarda reklâm derslerinde yapılan afiş çalışmalarının konuları: Eskimolara buzdolabı satışı, yaz aylarında kömür satışı, korsan üretimi ve mobilya satışı ile ilgili afişler olarak belirlenmiştir. Bu çalışmalarla hedeflenen kazanımlar genel olarak, empati, kendini ifade etme, duyarlılık, iletişim ve farkındalık olarak belirlenmiştir. Bu çalışmalar sırasında üretilen afişlerle yaratıcı drama çalışmalarından önce üretilen afişler birbirleriyle karşılaştırılmış ve aralarında önemli farklılıklar olduğu gözlemlenmiştir (bkz. Şekil: 3).
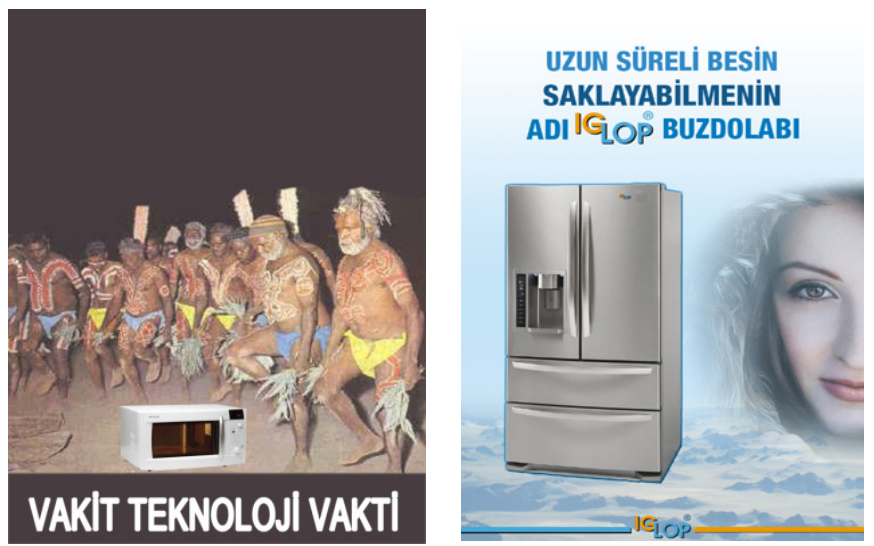

(Şekil: 3) Yan tarafta, yaratıcı drama çalışmalarından önce yapılan (soldaki) ve yaratıcı drama çalışmaları sırasında yapılan (sağdaki) iki afiş yer almaktadır. İki afiş arasında niteliksel anlamda önemli farklılıklar olduğu ve yaratıcı drama çalışmaları sırasında yapılan afişin birçok yönden (estetik duyarlılık, renk kalitesi, özgünlük, seslenilen kesimle kurulan empatinin afişe saygı biçiminde yansıması gibi) çok daha kaliteli olduğu kolaylıkla görülebilmektedir. 
_ Buna paralel olarak, bu çalışmalar içinde özellikle korsan üretimle ilgili yapılan etkinlikler sonunda üretilen afişlerin özel bir önemi olduğu düşünülmektedir. Çünkü bu afişler birbirine zıt iki bakış açısıyla üretilmişlerdir. Korsan üretimle ilgili yapılan drama etkinlikleri bu araştırmanın sonunda örnek olarak verilmiştir. (bkz. Ek 1).

Bu kampanyanın konusu, kültürel ve sanatsal ürünlerin "korsanlarının üretilmesi” olarak saptanmıştır. Ancak bu kampanyada öğrencilerden birbirine tamamen karşı; biri korsana karşı çıkan, diğeri korsanı destekleyen iki proje için fikir üretmeleri sağlanmaya çalışılmıştır. Projelerin kapsamında düşünsel arka planın (korsana neden "evet" ya da "hayır" dediklerini inandırıcı, geçerli gerekçelerle desteklemeleri) yaratıcı strateji (savundukları fikri en doğru, anlaşılır, sade ve abartısız bir mesaja ve bu mesajın aktarılacağı slogan ve görsellere karar verme) ve uygulama çalışmalarının yer alacağı yaratıcı drama etkinlikleri planlanmıştır.

Korsanla ilgili yaratıcı drama etkinliklerinde, özgün çok sayıda düşünce ortaya çıkmış, öğrenciler de ortaya çıkan bu düşünce çeşitliliği karşısında şaşırdıklarını ifade etmişlerdir.

Bu düşüncelerden bazıları şunlardır: "Korsana evet, çünkü çağımız değişmektedir, dolayısıyla sanatçılar geçinmek için kaset, kitap satmaktan vazgeçsinler, üstelik sanatçılar geçinmenin değil "süper lüks" yaşamanın derdindeler. Yani korsanla kimsenin ekmeğiyle oynanmamaktadır. Korsana evet, çünkü sanatçılar yoksul halkın kitap okumasını, müzik dinlemesini bile paraya bağlamak istiyorlar. Öğrencinin kitap alacak parasının bile olmadığı bilinmesine rağmen korsan ürün alınca hırsız gibi damgalayan kampanyalar düzenleniyor. Korsana evet çünkü özellikle korsan almalı ki büyük şirketler ve tekeller zarar görsün. Paranız varsa bile korsan alın. Korsana evet çünkü "bandrolcü vergi hırsızları ve yoksul halkın tepesindeki sömürücü sözde sanatçılar ve yazarlar” bu ülkenin karanlığa gömülmesini istiyorlar. Bu ülkede insanlar kitap okuma alışkanlığına sahip değilse, bunda kitabın pahalı olmasının etkisi büyüktür. “

"Korsana hayır, çünkü korsan emek hırsızlığıdır, üretmenin cezalandırılmasıdır. Korsana hayır, çünkü korsan kalitesizliktir, insanı okumaktan, film izlemekten, müzik dinlemekten soğutur. Korsana hayır, çünkü korsan vergi ödemez ve hepimizin cebindekini çalar, namuslu iş yapanları da sömürüye davet eder."

Burada dikkate değer en önemli nokta, yukarıda bir kısmına yer verilen düşüncelerin karşıt iki grup arasındaki bir tartışmadan alınmaması; herhangi biröğrencinin birbirine karşıt düşünceler üretebilmesidir.

Bunun bir başka anlamı, olaylara ve olgulara farklı yönlerden bakabilmektir. Bu, grafik tasarım için de -genel anlamda- sanat için de çok önemli bir eşiktir. Bunda, uygulanan yaratıcı drama çalışmalarının payının büyük olduğu düşünülmektedir. Çünkü sanat öncelikle belirlenmiş kalıpların dışına çıkmaya ve farklı bakış açılarıyla düşünebilmeye dayanır. Çakır İlhan’a göre (2007: 140); “...yaratıcı düşüncenin diğer düşüncelerden farkı, değişik olmasıdır.” Bu değişim hayata farklı ve çok yönlü bir yaklaşımla gerçekleştirilebilir. Burada, diyalektik düşüncenin temel dayanağının da çatışma ve çelişki yasalarına (tezantitez ve sentez) bağlı olduğunu ve her türlü değişimin temelini çatışmanın oluşturduğunu anımsatmak gerekir. Yani, “...yaratıcılık aynı zamanda içinde çatışmayı da barındırır.” (Çakır İlhan, 2007: 140). Ancak bu çatışma sayesindedir ki senteze, değişime ve doğrulara ulaşmak mümkün olabilmektedir. 
Belli kalıplarla, dogmatik düşüncelerle hareket ederek, kendi doğruları dışında doğruların olabileceğini reddederek, kendileri gibi düşünmeyen insanları dışlayarak iyi bir reklâmcı olunamayacağı gibi, iyi bir sanatçı da olunamamaktadır. Öyle anlaşılıyor ki, yaratıcılık ve yaratıcılığa ulaşma yöntemleri anlamında grafik tasarım, yaratıcı drama ve reklâmcılık arasında düşünülenden daha da fazla ilişki ve örtüşen yön bulunmaktadır. Dolayısıyla, yaratıcı dramayla desteklenen, bu arada çok yararlı reklâmcılık tekniklerinin de öğrenildiği bu kampanya sonucunda ortaya çıkan öğrenci çalışmalarının, önceki çalışmalara kıyasla bir hayli başarılı olduğu gözlemlenmiştir (Bkz. Şekil: 4).
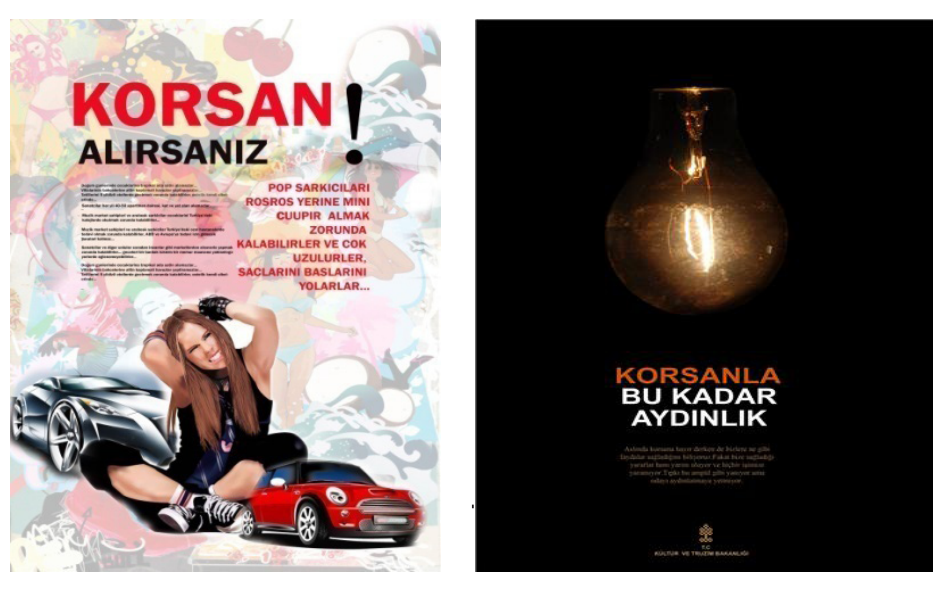

(Şekil: 4) Yaratıcı drama çalışmalarının da etkisiyle öğrencilerin yaptığı çalışmalarda önemli kazanımlar elde ettikleri yandaki afişlerden anlaşılmaktadır. Aynı öğrencilere ait ama birbirine karşıt düşüncelerle üretilmiş yandaki iki afiş örneği olaylara ve olgulara çok yönlü ve farklı yaklaşımlarda bulunmanın, grafik tasarım için önemini göstermektedir.

\section{Bulgular}

4 hafta boyunca reklâmcılık derslerinde uygulanan yaratıcı drama çalışmaları süresince öğrencilerin duygu ve düşüncelerini almak için yazdırılan mektuplardan elde edilen bulgular, içerik analizi ile değerlendirilmiş ve aşağıdaki sonuçlara ulaşılmıştır. İçerik analizi çalışmaya katılan grafik tasarımı bölümü öğrencilerinin grafik tasarım alanının gerektirdiği kıstaslar göz önünde tutularak gruplandırılmış ve yorumlanmıştır.

\section{Kendini İfade Etme}

Grafik Tasarım Bölümü öğrencileriyle yaratıcı drama yöntemi ile yapılan çalışmaların sonucunda kendini ifade etme teması ile ilgili görüşleri aşağıda özetlenerek verilmiştir

“...sanırım şimdi çalışmalarımı daha iyi anlatabilirim."

“...yaşayarak öğrenme deneyimi gibi bir şeydi gerçekten.”

“... drama ile kendimi daha rahat ifade etmeye başladım."

“... daha hazır cevap birisi oldum sanki.”

“... topluluk önünde konuşurken bildiklerimi unutuyordum. Drama sürecinde yaptığım doğaçlamaların bana çok faydası oldu."

“... çocukluğumdan beri utangaç bir yapım vardı, tümüyle atmış değilim ama drama çalışmaları bana iyi geldi." 
Öğrenciler daha önce topluluk önünde konuşurken bildiklerini unuttuklarını ancak yaratıcı drama çalışmalarından sonra kendilerini daha rahat ifade etmeye başladıklarını ifade etmişlerdir.

\section{Farkındalık}

Yaratıcı drama çalışmaları sürecinde yapılan kendini tanıma, güven kazanma ve yaşama bakışlarını geliştirme çalışmalarının öğrencilerin çeşitli konularda olduğu gibi farkındalık kazandırmada konusunda da etkili olduğu gözlenmiştir.

“...daha önceki çalı̧̧malarımı bilinçli bir şekilde yapmıyordum. Drama çalışmalarının bunu anlamamda büyük faydası oldu."

“... çalışmalarımızı yürütürken sesleneceğimiz hedef kitleyi de, onlara seslenirken kullanacă̆ımız dili de daha özenli seçeceğim artı.. '”

“... yalnızca grafik tasarımda değil, hayat içinde de fazla bir şey üretebileceğimi düşünemezdim, denedim ve yaptım. Kendimi daha iyi hissetmeye başladım."

“... şimdi reklâmları izlerken, afislere bakarken daha farklı bir pencereden bakıyorum. Daha önce hiç bilinçli reklâm izlememişim."

“... ders içinde yaptığımız projeler ve drama çalışmaları sonunda grafik tasarıma da, sanata da farklı bir pencereden bakabiliyorum".

Yukarıda verilen görüşler incelendiğinde, öğrencilerin yaratıcı drama etkinliklerinin farkındalık düzeylerini etkilediği ortaya çıkmıştır. Bu sonuca göre öğrencilerin kendi alanlarının gereği olan yaratıcılık, yeni fikir üretme, seslenilecek insanları tanıma gibi çeşitli alanlardaki farkındalıklarının geliştiği söylenebilir. Bir başka ifadeyle öğrencilerin yaratıcı drama sürecinin sonunda grafik tasarımı alanını yeni baştan keşfetmeye başladıkları, grafik tasarımına, sanata ve yaşama dair farkındalık düzeylerinin olumlu yönde etkilendiği söylenebilir.

\section{Empati}

Hedef kitleye mesaj iletme işiyle uğraşan grafik tasarım için hedef kitlenin tanınması adına anahtar bir kavram olan empati ve duyarlılık kazanma konusunda yaratıcı dramanın bölüm öğrencilerine çok önemli katkılar sağladığı söylenebilir. Öğrencilerin bu tema ile ilgili örnek ifadeler aşağıda özetlenerek verilmiştir.

“... artık kime mesaj ileteceğimi bilmeden grafik tasarım yapamayacağımı çok iyi biliyorum."

“... hedef kitleyle empati kurmadan yaptı̆̆ım tasarımların boş olduğunu şimdi çok iyi anlayabiliyorum. Kızılderililerle alay edip onlara mal satmaya çalışmış̧ım örneğin." 
“... bize, sesleneceğimiz insanlarla empati kurmamı gerektiğini 1. sınıftan beri anlatıyorsunuz ama ancak bir korsan satıcısını oyunda canlandırdiğım zaman dediklerinizi anladım."

“... olaylara farklı açılardan bakılabileceğini hep söylerdim; ama ilk defa bu derste öğrendim. Yaptığıma inanamadım, çünkü karşı olduğum bir şeyi savunma oyununda başka birisinin bakış açısıyla ciddi ciddi düşünmeyi başardım."

Öğrencilerin ifadelerinden yaratıcı drama çalışmaları sonrasında başka insanların ve düşüncelerin, başka yaşam biçimlerinin farkına vardıkları anlaşılmıştır. İnsanların bulundukları duruma göre düşüncelerinin de değişeceğinin kavranması ve farklı olana anlayışla yaklaşılması, ona tahammül edilmesi gerektiğidir. Drama çalışmaları sonucunda doğrunun her zaman tek olmayacağı; insanın bulunduğu yer ve konuma göre değişebileceği kazanımına ulaşıldı̆̆ı görülmüştür.

\section{İletişim}

Diğer adı Görsel İletişim Tasarımı Bölümü olan ve alanın niteliği gereği sürekli insanlarla iletişimde bulunması gereken Grafik Tasarım Bölümü öğrencileri için iletişim konusunda önemli kazanımlar elde edildiği öğrencilerin aşağıdaki ifadelerinden anlaşılmaktadır:

“... aynı sınıfta aynı stüdyoda iki yıldır beraber çalıştığım arkadaşlarımın ürettikleri fikirleri görünce şaşırdım. Birçok arkadaşımı yeni yeni drama çalışmaları sayesinde daha yakından tanıdı̆̆ımı söyleyebilirim."

“... drama çalışmaları sayesinde arkadaşlarımla olduğundan daha iyi bir iletişim kurdum."

“... oynadı̆̆ımız oyunlarla birbirimizi daha yakından tanıma firsatımız oldu.”

“... normalde konuşmadiğım arkadaşlarımla oyun sayesinde sıcak bă̆larımız oldu, çok ĕglendik."

“... oyun oynamanın çok güzel tarafları var, çocukluğumu hatırladım.”

Öğrencilerin, drama çalışmalarının sonucunda, arkadaşlarını daha yakından tanıdıklarını, daha önce paylaşımda bulunmadığı arkadaşları ile sıcak ilişkileri olduğunu ve daha iyi iletişim kurdukları görülebilir. 


\section{Sonuç ve Öneriler}

Grafik Tasarım Bölümü, Reklâmcılık derslerinde gerçekleştirilen yaratıcı drama uygulamalarına katılan öğrencilerin yazmış oldukları mektupların içerik analizleri yapılmış ve şu sonuçlara ulaşılmıştır:

Öğrencilerin kendi ifadelerine göre: "Yaratıcı darama, grup içi iletişimi sıklaştırmış, öğrencilerinin kendilerini tanımalarına ve güven duymalarına, kendilerini daha rahat ifade etmelerine katkıda bulunmuştur."

Bunun yanı sıra, çalışmalara katılan öğrencilerin yaratıcı drama süreci sayesinde hem kişisel gelişim hem de grafik tasarım alanındaki eksikliklerini görmüş olmaları ve bu eksiklikleri gidermenin yollarını aramaya başlamaları da önemli bir kazanım olarak ele alınabilir. Bu kazanımların en önemli göstergelerinden biri, öğrencilerin kendilerinden farklı kişi ve düşüncelere yaklaşırken takındıkları önyargıları kırma çabalarıdır. Bu sayede öğrencilerin çevrelerine, diğer insanlara karşı daha duyarlı ve hassas davranmaya başladıkları gözlemlenmiştir. $\mathrm{Bu}$ sonucu hem öğrencilerin yaptıkları grafik tasarımlardan hem de kendi ifadelerinden çıkarmak mümkündür. Örneğin başta, önyargılardan dolayı bazı toplulukları (örneğimizde Kızılderilileri) aşağılayan tavır ve bu tavrın yansıtıldı̆̆ı reklâm çalışmaları, yaratıcı drama sürecinden itibaren yerini, kendilerine yabancı ve uzak olsa bile insanları (örneğimizde Eskimoları) anlamaya çalışan, onlara saygıyla yaklaşan bir anlayışa dönüşmüştür. Bu durumu destekleyen bir başka örnek ise, "korsan” projesinde öğrencilerin hem korsanı destekleyen hem de karşı çıkan sağlam, tutarlı ve önyargılardan, klişelerden arınmış yaratıcı çalışmalar üretebilmeleridir. Korsan projesinde öğrenciler role girerek, yaratıcı dramanın yaşantısal öğrenme sürecine katılarak doğrunun her zaman tek olmadığını; insanın bulunduğu yer ve duruma göre değişiklik gösterebileceğini görüp yaşadıkları deneyimleri grafik tasarıma aktarmışlardır. Bu çalışma bir bakıma, yaratıcılığının önünde bir engel olarak duran klişelerden, önyargılardan kurtulmaya karar veren insanın hayal gücü ve sanatsal bakış açısının gelişebileceğinin bir örneği olarak da görülebilir.

Öğrencilerin çalışmalar sırasında kendi ifadeleriyle "mutlu olmaları, çocukluklarına dönmeleri ve eğlenmeleri" ise kişisel gelişim açısından önemli kabul edilmelidir. Mutluluk duygusunun iletişimi kolaylaştırdığı, sanatsal bakış açısı ve çerçevesini genişlettiği, yaşama olumlu bir bakış açısı kazandırdığ düşünüldüğünde uygulanan yaratıcı drama çalışmalarının bu açıdan da önemli sonuçları olduğu söylenebilir.

Kısacası, uygulanan bu yaratıcı drama çalışmaları sayesinde öğrencilerin hem kişisel gelişim açısından hem de kendi alanlarıyla ilgili olarak önemli kazanımlar elde ettiği sonucuna ulaşılmıştır. Bu deneyimin sunduğu sonuçlar çerçevesinde aşağıdaki önerilerde bulunulmuştur:

1. Güzel Sanatlar Fakültesi Grafik Tasarım Bölümü Reklâmcılık derslerinde yaratıcı drama yöntemine yer verilmelidir.

2. Yaratıcı Drama, Güzel Sanatlar Fakülteleri'nde ve Güzel Sanatlar Liseleri’nin müfredatında yer almalidir. 


\section{Kaynaklar}

Adıgüzel, Ö. (2006a). Eğitimde Yeni Bir Yöntem ve Disiplin. Yaratıcı Drama. Prof. Dr. İnci San'a Armağan: Yaratıcı Drama Yazıları: 1985-1998. Ed. H. Ömer Adıgüzel, 2. Bask1, Naturel Yayıncılık, Ankara.

Adıgüzel, Ö. (2006b). Yaratıcı drama kavramları, bileşenleri ve aşamaları. Yaratıcı Drama Dergisi, 1, 17.

Aykaç, N. (2005). Öğretme ve Öğrenme Sürecinde Aktif Öğretim Yöntemleri. Naturel Yayınları, Ankara, 137.

Bach, G. L. (1958). Economics. Prentice Hall, Inc., New Jersey,

Beckman, J. (1968). “Is Advertising Wasteful?”, Journal of Marketing, New York, January.

Caves, R. (1964). American Industry, Prentice Hall, Inc., New Jersey.

Çakır İlhan, A. (2007). Yaratıcı drama ile örtüşen çağdaş sanat akımları. Yaratıcı Drama Dergisi, Cilt:

1, Say1: 3-4, 140.

Kılkış, Y. (1988). “Reklâmcının Sosyal Sorumluluğu”. Der. Ali Atıf Bir ve Fermani Maviş. Dünyada ve Türkiye'de Reklâmcılık: Reklâmın Gücü. Bilgi Yayınevi, Ankara, 89.

McConnel, C.R. (1963). Economics, McGraw Hill Book Company, Inc., New York.

Morgens, H. J. (1960). “Nonsense About Advertising” Advertising Age, New York, November,

Okvuran, A. (2006). Yaratıcı Dramanın Kullanılacağı Alanlar. Prof. Dr. İnci San'a Armă̆an: Yaratıcı Drama 1985-1998 Yazılar. Ankara: Naturel Yayıncılık 196.

Sağlam, T. (2006). Gavin Bolton: Drama-Sanat-Öğrenme. Yaratıcı Drama Dergisi, Cilt:1, Sayı:2, 64.

San, İ. (2006). Ĕgitimde Yaratıcı Drama. Yaratıcı Drama. Prof. Dr. İnci San'a Armağan: Yaratıcı Drama Yazıları: 1985-1998. Ed. H. Ömer Adıgüzel, 2. Bask1, Naturel Yayıncılık, Ankara. 53, 54,56.

San, İ. (1991). Yaratıcı drama: Eğitsel boyutları. Buca Eğitim Fakültesi, 1. İzmir Eğitim Kongresi, 25-27 kasım 1991, İzmir, 558-565

Stigler, G.J. (1966). The Teory of Price. 3. Bask1, The McMillan Company, New York.

Warkham, J.M. (1964). "Is Advertising Important in the Soviet Economya?" Journal of Marketing, New York, April.

Warne, E. (1962). Colston. “Advertising-A Critic's Views", Journal of Marketing, New York, October.

\section{EK 1: Grafik Tasarım Bölümü Reklâmcılık Dersinde "Korsan Üretim” ile ilgili Afiş Tasarımının Gerçekleştirildiği Oturumların İçeriği}

Ders: Reklâmcılik

Konu: Korsan üretim ile ilgili afiş tasarımı

Kazanımlar:

Korsan üretim hakkında bilgi sahibi olur.

Farklı bakış açıları geliştirir. 
Bakış açısını afişe yansıtır.

Grup çalışmalarına katılmakta istekli olur.

Afiş yoluyla kendini ifade eder.

Eleştirel bir bakış açısı ile yorumlar.

Süre: 6 Ders Saati

Grup: 2009-2010 Grafik Bölümü 3. Sınıf öğrencileri

Öğrenme Alanı: Afiş Tasarımı

Araç-Gereçler: Kalem, kâğıt, boya, PC, Photoshop ve Corel Drawn programları

Mekân: Erciyes Üniversitesi GSF Grafik Tasarım Bölümü Atölyeleri

Yöntem ve Teknikler: Yaratıcı Drama (Doğaçlama, Rol Oynama, Donuk İmge, Eş Zamanlı

Doğaçlama, Öğretmenin role girmesi, Röportaj )

\section{Hazırlık-Isınma}

\section{Etkinlik}

Öğrenciler ayakta çember biçimindedir. Öğretmen oyunu ve kurallarını göstererek anlatır.

Çemberdeki öğrencilerden birisine top atılır. Top atılırken topu atan kişi korsan üretimle ilgili bir sözcük söyleyerek topu karşısındakine atar. İkinci kişi bir öncekinin söylediği sözcüğün dışında korsan üretimle ilgili sözcük söyleyerek topu üçüncü kişiye atar. Öğrencilerin tamamının katılımı sağlanıncaya kadar oyun devam eder. Oyunda top aynı kişiye ikinci kez atılamaz.

\section{Etkinlik}

Öğrenciler sayma yoluyla (1-2) iki gruba ayrılır. Birinci grup dış çember biçiminde; ikinci grup iç çember biçiminde yer alır. Ortada bir öğrenci ebe olarak yer alır. İki grubun yüzleri de içe dönüktür. İç çemberdeki öğrenciler işportacı, dış çemberdeki öğrenciler zabıta olarak adlandırılır. Ortada ebe olan öğrenci işportacı ya da zabıta dediğinde adı söylenen grup kendi içinde yer değiştirmeye çalışır. Onlar yer değiştirirken ebe de yer kapmaya çalışır. Yer bulamayan öğrenci, ebe olur (Dev -Cüce oyunundan uyarlanmıştır.)

3. Etkinlik (Korsan, Katil Kim oyunundan uyarlanmıştır)

Öğretmen, çember biçiminde ayakta duran öğrencilere "Korsan” adlı oyunu oynayacaklarını söyler.

Öğrenciler mekanda serbestçe yürürler. Bir süre sonra öğretmenin yönergesiyle herkes olduğu yerde durur ve gözlerini kapatır. Öğretmen, öğrencilerin arasında dolaşırken öğrencilerden birisinin omzuna dokunur. Buna göre, dokunduğu öğrenci "zabıta” olur. Öğretmenin işaretiyle öğrenciler gözlerini açar ve mekanda korsan satıcı olarak dolaşırlar. Ebe olarak seçilen zabıta, diğer öğrencilere hissettirmeden herhangi bir öğrenciye göz kırpması halinde göz kırpılan öğrenci oyun dışı kalır. Göz kırpılan öğrenci, içinden beşe kadar sayıp “Ah! Ben Yakalandım!” deyip oyunun dışına çıkar. Diğer öğrencilerin amacı, ebeyi (zabıtayı) bulmaktır. Ebenin göz kırpmasını fark eden diğer öğrenciler bunu öğretmenin kulağına fisıldar. Eğer, gördükleri kişi öğretmenin seçtiği ebeyse (zabitaysa), ebe oyunun dışında (üç korsan satıcı doğru olarak tahmin ederse) kalır. Yanlış tahminde bulunulursa korsan satıcı oyun dışında kalır. Zabıtanın tüm korsan satıcıları yakalayana kadar oyun devam eder. 


\section{Ara Değerlendirme}

Öğrencilere oynadıkları oyunlar sırasında neler hissettikleri ve düşündükleri sorulur. Konuya ilgilerinin çekilip çekilmediği anlaşılmaya çalışılır.

\section{Canlandırma}

\section{Etkinlik}

Öğretmen, çember halindeki öğrencilerden 1'den 8'e kadar saymalarını ister. Rakamları aynı olan öğrencilerin ikili grup olmaları istenir. Grup elemanlarının kendi aralarında A ve B olarak belirlenmeleri istenir.

Öğretmen: A’lar, sizler önemli bir iş adamı veya kadınısınız, sizin için çok önemli bir toplantıya yetişmek üzere yola çıktınız ve vapurdasınız. Toplantıya girmeden önce, toplantıda yapacağınız sunuya son bir defa göz atmak istiyorsunuz. Gece geç saatlere kadar çalıştınız ve hiçbir biçimde zaman kaybına tahammülünüz yok.

B’ler, sizler bir seyyar satıcısınız. Elinizdeki ürünleri satmak istiyorsunuz. Çünkü tek geçim kaynağınız budur. Az ilerde oturan ve maddi durumunun iyi olduğunu düşündüğünüz kişiye doğru ilerliyorsunuz. Ürünü ona satmaya kararlısınız."

Yönerge verildiğinde tüm gruplar eş zamanlı olarak doğaçlamalarına başlar. Bütün gruplar belirli bir süre doğaçlamalarını gerçekleştirdikten sonra, roller değiştirilir ve yine eş zamanlı olarak doğaçlamalar yapılır. Bir süre sonra öğretmen grupları ayrı ayrı izleyeceklerini söyler. Tüm grupların canlandırmaları izlenir.

\section{Ara Değerlendirme}

1.Alıcı rolündeyken neden ürünü satın aldınız?

2.Alıcı rolündeyken neden ürünü satın almadınız?

3. Satıcı rolündeyken elinizdeki ürünleri satmak için neden ısrarcı davrandınız?

4. Ürün satamazsanız ne olurdu?

\section{Etkinlik}

Öğretmen, çember halindeki öğrencilerden sırayla 1'den 4'e kadar saymalarını ister. Aynı rakamı söyleyenler bir araya gelirler. Oluşan 4 gruba gazete kâğıtları, makas, pastel boya ve yapıştırıcı verilir. Gruplardan, elindeki malzemeleri kullanarak 15 dakika içerisinde korsan üretimi yapılan bir ürünü tasarlamaları istenir. Sunumlar sonucunda, tasarlanan ürünlerden bir tanesi seçilir. 1. gruba seçilen ürünün, Planlama ve Tasarım; 2. Gruba, Üretim; 3. Gruba, Pazarlama; 4. Gruba, Satıș aşamalarını içeren ve 4 donuk imgeden oluşan canlandırma hazırlamaları istenir. Grupların hazırladığı canlandırmalar izlenir.

\section{Etkinlik}

Öğrencilerden, şehir meydanında farklı meslek gruplarına ait insanlar olarak bulunmaları istenir. Bir muhabir onlarla korsan üretim ve satışla ilgili röportaj yapacaktır. Öğrencilerden girdikleri rol çerçevesinde sorulara cevap vermeleri istenir. Muhabir rolüne giren öğretmen, değişik meslek gruplarının korsana karşı tutumunu araştırmaya yönelik sorular sorar. Örnek: "Elinizdeki kitap korsan üretim mi?”, "Neden korsanı tercih ettiniz ya da etmediniz?”, “Şu sattığınız CD’lerin kaçak olduğunu biliyor 
musunuz?", "Korsan CD satmanın suç olduğunu biliyor musunuz?”, "Kullandığınız çanta kaçak mı acaba?”, “Kaçak üretim, orijinal kadar kaliteli mi?”, “Üzerinizdeki tişörtü mağazadan mı aldınız, seyyar satıcıdan mı?”, “Kaçak ürün satın aldığınızda devlete verdiğiniz zararı biliyor musunuz?”, “Seyyar satıcıların vergi vermeden kazanç sağlaması konusunda ne düşünüyorsunuz?” gibi sorular yöneltilir.

\section{Etkinlik}

Öğretmen bütün öğrencilere kalem ve kâğıt dağıtır. Kâğıtların bir yüzünde, "Korsana hayır! Çünkü...", diğer yüzünde ise; "Korsana evet! Çünkü..." yazılıdır. Öğrenciler verilen kâğıtlara düşüncelerini maddeler halinde yazarlar ve katlayıp ortaya atarlar. Öğretmen kağıtları toplar, karıştırır ve öğrencileri sayma yöntemiyle (1-2) iki gruba ayırır. 1'lerin grubuna topladığı kâğıtların yarısını, 2'lere de diğer yarısını verir. 1'lerden ellerindeki kâğıtlarda yazılı gerekçelerden yola çıkarak "Korsana evet!” yönünde; 2'lerden de yine ellerinde yazılı kâğıtlarda yer alan gerekçelerden yola çıkarak “Korsana hayır!” yönünde bir öykü yazmalarını ister. Öyküler yazıldıktan sonra 1'ler 2'lere, 2'ler de 1'lere öykülerini vereceklerdir. Her grup elindeki öyküden yola çıkarak bir canlandırma hazırlar ve canlandırmalar izlenir.

\section{Değerlendirme}

\section{Etkinlik}

Öğrenciler sayma yöntemiyle (1-2-3-4) 4 gruba ayrılır. Her gruba 2 adet büyük resim kâğ 1 1 verilir. Her grup kâğıdın bir yüzüne korsanı destekleyen, diğer yüzüne de korsana karşı çıkan sloganlar yazacaklardır. Yazma işlemi bitince gruplardan ellerindeki kâğıtları yandaki gruba vermeleri istenir. Her grup önüne gelen kâğıtlara yazılı sloganları destekleyen görsel öğeler bularak korsanı destekleyen ve karşı çıkan iki ayrı afiş taslağı çıkarır. Öğrenciler dörder kişilik ekipler olarak taslaklarını, çıkardıkları afişleri bilgisayar laboratuarında orijinal lay aoutlar haline getirirler. Çalışmanın sonunda yapılan afişler sergilenir ve değerlendirme yapılarak en iyi iki afiş seçilir.

\section{Etkinlik}

Öğrenciler, 1-2 diye sayarak 2 g rup oluşturulur. Oluşturulan gruplara seçilen afişler verilir. $\mathrm{Bu}$ afişlerden yola çıkarak (korsan üretim hakkında bilgilerinde verildiği reklam filmi hazırlamaları yönergesi verilir. 


\title{
Summary \\ Usıng of Creatıve Drama Method in Advertısıng Courses of Graphıc Desıgn Department and Evaluation of This Method with to use of Student Opınıons
}

\section{A. Hamit GÜMÜŞLÜ*}

\author{
Erciyes Üniversity
}

This study investigates the effects of using creative drama on education in advertising courses of graphic design department. The study was carried out with third grade students of Visual Communication Design, Faculty of Fine Arts of Erciyes University in spring semester of 2009-2010.

In advertising courses of graphic design departments of universities' fine arts faculties, the basic concepts of the field is taught theoretically and practically to the advertiser candidates. However, there are some deficiencies while conducting the advertising courses. For instance, it was observed that the students were having difficulties with expressing their projects and even communicating about subjects that is related to their own field. The significance of communication, self expression and presentation skills in advertisement taken into consideration, a method was started to be searched to solve these problems.

At this point, it was thought that with the advantages of creative drama, the deficiencies would be overcome. For instance, creative drama within the process of group working provides benefits as learning by living as well as developing verbal expression and socialization skills. (San, 2002: 84). In short, with the new practice methods of creative drama, it is considered to be made significant contribution to the field of graphic design education, as they are processes depending on experience and develop the group communication skills and creativity, as well.

\section{Advertising Concept and Education}

Advertising is a case that was originated from the era of free competition capitalism and it is hardly meant to create a monopoly or unfair competition alone. Advertising, above all, is an effective method of marketing, in any condition. When utilized properly, it makes remarkable contributions to national economy and consumers. Nevertheless, when misused, there may be severe costs, first of all for consumers and national economies. Advertising courses in graphic design departments should be conducted considering the fact that advertising sector has been in a serious degeneration and the solution of the problem lies in modern and contemporaray education methods.

\section{Why Creative Drama in Advertising Courses ?}

In advertising courses in graphic design departments, first of all it should be pointed out to the advertiser candidates that advertising is not just selling goods, but at the same time it is a field that has societal responsibilities. However, achieving these goals does not seem to be likely with the current conditions and courses. It is considered to make use of creative drama courses due to the possibility that 'creative drama can be taught as an individual course as well as it can be used as a method for teaching other courses' (Okvuran, 2006: 196).

\footnotetext{
* Assistant Professor, Erciyes University of Visual Communication Design, e-mail:hgumuslu@erciyes.edu.tr
} 
It is easier to reach the goal if the graphic designer knows who he or she addresses, investigate how they feel and what they need. At this point, it is crucial that the designer develop empathy rather than have cognitive information. However, this is a serious issue and Students are prone to cliché thoughts and preconceptions rooted in educational system they were coming from or any other conditions. At this point, the importance of abilities like self knowledge, empathy and anti egocentricity that students can gain with creative drama methods in advertising courses of universities comes on the scene.

\section{Importance of the Study}

In the root of many social problems, there are incorrect interpretation, acting with prejudices and lack of education. Universities must have a contribution to societies and play a role to avoid these problems. It is impossible to state that the methods of graphic design education in our country meet the needs of modern living. Advertising courses in this area as a part of the same picture have some deficiencies as well. This study could make a significant point at showing the advantages of using creative drama in graphic design education in general and advertising courses in specific.

\section{Aim of the Study}

The primary aim of this study is to revise the modern in technology but classic in conception educational system in graphic design departments and show the possible contribution to graphic design education. Yet, the ultimate aim is to make a contribution to the process of utilization of modern and contemporary educational methods, creative drama in advertising courses as foremost, in graphic design departments in universities.

\section{Operation of the Implementation}

The implementation is carried out with third grade six female and ten male, total sixteen advertising students of Erciyes University, Department of Fine Arts, aged between 19 and 26 in graphic design studios for 3 weeks.

\section{Conclusion and Advices}

Advertising courses in universities is given to advertiser candidates for teaching the principles of advertising. However today, there are many deficiencies in the current education system conducted in graphic design departments. This implementation is considered and carried out as a solution for the mentioned problems. In short, the study about conducting creative drama methods in advertising lessons concludes that creative drama in graphic design departments could make positive contributions to the education.

At the end of the study some suggestions are presented:

1. Creative drama lessons should be including among the elective courses in the programs of fine arts faculties.

2. Creative drama lessons should be including in the programs of high schools of fine arts. 